\title{
Breast Cancer and Pregnancy: A Review
}

\author{
1Department of Internal Medicine, Dr. Pablo O. Torre Memorial \\ Hospital, Bacolod City, Negros Occidental, Philippines \\ 2Department of Internal Medicine, Corazon Locsin Montelibano \\ Memorial Regional Hospital, Bacolod City, Negros Occidental, \\ Philippines \\ ${ }^{3}$ Department of Internal Medicine, Premiere Medical Center, \\ Cabanatuan City, Nueva Ecija, Philippines
}

Frederic Ivan L. Ting ${ }^{1, \odot ~ N o r m a n ~ F . ~ C a b a y a ² ~ B o b b y ~ G . ~ d e ~ G u z m a n ~}{ }^{3}$

\author{
Address for correspondence Frederic Ivan L. Ting, MD, \\ Department of Internal Medicine, Dr. Pablo O. Torre Memorial \\ Hospital BS Aquino Drive, Bacolod City, Negros Occidental 6100, \\ Philippines(e-mail: flting@rivermedcenter.net).
}

Asian J Oncol 2021;7:60-63.
Abstract
Keywords
- breast cancer
- pregnancy
- review

Breast cancer is one of the most commonly encountered types of malignancy during pregnancy. Here, we review the most recent data with regards to this special patient population. Current evidence shows that it is appropriate for oncologists to treat these patients carefully with a coordinated multidisciplinary approach.

\section{Breast Cancer and Pregnancy}

Breast cancer is one of the most commonly encountered types of malignancy during pregnancy. ${ }^{1,2}$ In fact, up to $4 \%$ of all breast cancers occur during this period. ${ }^{3,4}$ This presents a unique scenario to both the patient and the physician since the patient faces the fear of how the cancer can affect her own personal survival and that of the fetus. The managing oncologist may have limited experience in managing these patients due to their rarity. Furthermore, the holistic management of the pregnant patient with breast cancer also involves ethical and moral constructs. ${ }^{5}$

Historically, physicians believed that breast cancer in pregnant patients were more aggressive, convincing some to forgo the treatment of these patients. ${ }^{6,7}$ As we learned about the relationship and the role of the estrogen receptors in breast cancer, physicians considered pregnant patients with breast cancer to have a poor prognosis, leading to the concept of therapeutic abortion to augment survival. ${ }^{6,89}$ Adding to its poor prognoses is the fact that majority are often axillary lymph node positive, with larger primary tumor size. Histologically, these tumors are often poorly differentiated, hormone receptor (HR) negative, and approximately $30 \%$ are human epidermal growth factor receptor 2 (HER2)positive. ${ }^{10,11}$

Previous reports on outcomes for these patients show mixed results as some have reported poor prognoses, while others are more encouraging. ${ }^{12-15}$ Here we review the most recent data with regard to this special patient population.

\section{Assessment}

Women presenting with a breast lump during pregnancy should be properly evaluated by a breast specialty team and appropriate diagnostic tests should be done. ${ }^{14}$ Mammogram of the breast maybe done safely with shielding and is reported to have an accuracy of $>80 \%{ }^{16}$ Ultrasound can also be used to assess the breast and regional lymph nodes, and to guide biopsy. Core needle biopsy is the preferred technique since it facilitates histologic confirmation and provides adequate tissue for HR and HER2 analyses.

The staging should be tailored to minimize fetal exposure to radiation. Bone scanning and pelvic X-ray or computed tomography are not recommended because of the possible effects of irradiation on the fetus. ${ }^{14}$

Assessment of pregnancy should include maternal fetal medicine consults and review of maternal risks and comorbidities. Documentation of fetal growth and development by ultrasound is a must. These patients should also be counseled regarding their disease, treatment options including their risks, and fertility-preservation opportunities.
DOI https://doi.org/ $10.1055 / \mathrm{s}-0041-1729348$ ISSN 2454-6798
(C2021. Spring Hope Cancer Foundation \& Young Oncologist Group of Asia.

This is an open access article published by Thieme under the terms of the Creative Commons Attribution-NonDerivative-NonCommercial-License, permitting copying and reproduction so long as the original work is given appropriate credit. Contents may not be used for commercial purposes, or adapted, remixed, transformed or built upon. (https://creativecommons.org/licenses/by-nc-nd/4.0/).

Thieme Medical and Scientific Publishers Pvt. Ltd. A-12, 2nd Floor, Sector 2, Noida-201301 UP, India 


\section{Treatment of Breast Cancer during Pregnancy}

The most common surgical procedure has been modified radical mastectomy. However, breast-conserving surgery is also possible if radiation therapy can be delayed to the postpartum period since there is growing evidence that breast-conserving therapy does not negatively impact survival. ${ }^{17,18} \mathrm{~A}$ review of the absolute and relative contraindications to sentinel node biopsy concluded that it should not be offered to pregnant patients with less than 30 weeks of gestation due to concerns of fetal exposure to radioactive material. ${ }^{19}$

The indications for systemic chemotherapy in the pregnant patient are similar to the nonpregnant breast cancer patients except that chemotherapy should not be given during the first trimester since this period has the greatest risk of fetal malformation. ${ }^{20-22}$ The risks of fetal malformation in the second and third trimesters are approximately $1.3 \%$, which is a rate similar to fetuses not exposed to chemotherapy. ${ }^{23}$ Fetal monitoring prior to each chemotherapy cycle is recommended. It is important to note that chemotherapy should not be given after the 35th week of pregnancy or within 3 weeks of planned delivery to avoid hematologic complications. One prospective study showed that 5-Fluorouracil (5-FU), doxorubicin, cyclophosphamide (FAC) chemotherapy is relatively safe to be given during the second and third trimesters. ${ }^{21}$ Data are limited regarding the use of taxanes during pregnancy, ${ }^{24-27}$ but weekly paclitaxel is recommended by the National Comprehensive Cancer Network should the physician decide to use it. Trastuzumab, endocrine, and radiation therapy are contraindicated during pregnancy due to concerns on their effects on the fetus such as oligohydamnrios or anhydamnrios, and renal failure. ${ }^{28-43}$

During the postpartum period, the Royal College of Obstetricians and Gynaecologists (London, United Kingdom) recommends that women should not breastfeed when taking trastuzumab or tamoxifen, because it is unknown whether these drugs are transmitted in breast milk.

Recommendations from different international organizations are shown in - Table 1.

Table 1 Recommendations from international organizations on the management of breast cancer in pregnant patients

\begin{tabular}{|c|c|c|}
\hline Management option & Society & Clinical recommendations \\
\hline \multirow[t]{3}{*}{ Diagnosis } & NCCN & $\begin{array}{l}\text { - Referral to a breast specialty team } \\
\text { - Mammogram with shielding } \\
\text { - Ultrasound of breast and axillary lymph nodes } \\
\text { - Biopsy: core needle (preferred), fine needle aspiration is an option } \\
\text { - If clinically indicated: } \\
\text { o Chest X-ray with shielding } \\
\text { o Liver and renal function assessment } \\
\text { o Ultrasound of the liver } \\
\text { o Screening MRI of thoracic and lumbar spine WITHOUT contrast }\end{array}$ \\
\hline & RCOG & - Bone scanning and pelvic X-ray/CT scans are NOT recommended \\
\hline & ESMO & $\begin{array}{l}\text { - Should be limited to those associated with the lowest exposure to ion- } \\
\text { izing radiation } \\
\text { - AVOID: } \\
\text { - Abdominal plain films } \\
\text { o Isotope scans } \\
\text { o CT scans } \\
\text { - SAFE: } \\
\text { o Chest X-ray with shield } \\
\text { o Abdominal ultrasound }\end{array}$ \\
\hline Local therapy & NCCN/ESMO & $\begin{array}{l}\text { - Modified radical mastectomy } \\
\text { - Breast conservation therapy possible if radiation therapy can be } \\
\text { delayed to postpartum period } \\
\text { - Sentinel lymph node biopsy contraindicated to pregnant women under } \\
30 \text { weeks gestation }\end{array}$ \\
\hline \multirow[t]{2}{*}{ Systemic therapy } & NCCN & $\begin{array}{l}\text { - Indications similar to nonpregnant patient } \\
\text { - Should NOT be given during the first trimester } \\
\text { - Chemo regimens: } \\
\text { o Anthracycline and alkylating agents } \\
\text { o FAC regimen-safe according to a prospective trial } \\
\text { o Weekly paclitaxel-recommended taxane regimen although data is } \\
\text { limited }\end{array}$ \\
\hline & NCCN/ESMO/RCOG & $\begin{array}{l}\text { - Contraindicated: } \\
\text { o Chemo during the first trimester } \\
\text { o Chemo after } 35 \text { weeks } \\
\text { o Trastuzumab } \\
\text { o Endocrine treatment } \\
\text { o Radiation treatment }\end{array}$ \\
\hline
\end{tabular}

Abbreviations: ESMO, European Society of Medical Oncology; NCCN, National Comprehensive Cancer Network; RCOG, Royal College of Obstetricians and Gynaecologists. 


\section{Prognosis of Breast Cancer during and after Pregnancy}

A large series that investigated the prognosis of pregnant breast cancer patients concluded that there were no observed differences in disease-free or overall survival on the basis of pregnancy at the time of diagnosis. ${ }^{14}$ This study, which involved a total of 311 patients, confirmed that pregnancy was not a factor in recurrence risk or risk of death for the pregnant patients examined.

Another study involving 333 pregnant patients also reported no differences in disease-free survival for pregnant or nonpregnant patients and an improved survival for those who became pregnant after successful breast cancer treatment. Hormone receptor status was found to have no influence on the relapse-free survival of the cohort. ${ }^{13}$

These reports provide convincing evidence that pregnancy does not have an impact on breast cancer. With a multidisciplinary approach the cancer can be treated, the pregnancy can be successful, and the outcome for both the mother and the neonate can be expected to be favorable. ${ }^{5}$

For the young patients with breast cancer who have not yet completed their desired family size, there is evidence showing that subsequent childbearing after treatment is unlikely to increase the risk of mortality. ${ }^{15}$

\section{Conclusion}

In lieu of level 1 evidence to address the management of breast cancer in pregnant patients due to the scarcity of data, it is appropriate for oncologists to treat these patients carefully with a coordinated multidisciplinary approach.

\section{Conflict of Interest}

None declared.

\section{References}

1 Smith LH, Danielsen B, Allen ME, Cress R. Cancer associated with obstetric delivery: results of linkage with the California cancer registry. Am J Obstet Gynecol 2003;189(4):1128-1135

2 Van Calsteren K, Heyns L, De Smet F, et al. Cancer during pregnancy: an analysis of 215 patients emphasizing the obstetrical and the neonatal outcomes. J Clin Oncol 2010;28(4):683-689

3 Wallack MK, Wolf JA Jr, Bedwinek J, et al. Gestational carcinoma of the female breast. Curr Probl Cancer 1983;7(9):1-58

4 Lethaby, AE, O'Neill, MA, Mason, BH, Holdaway, IM, Harvey, VJ. Overall survival from breast cancer in women pregnant or lactating at or after diagnosis. Auckland Breast Cancer Study Group. Int J Cancer 1996;67(6):751:755

5 Theriault RL, Litton JK. Pregnancy during or after breast cancer diagnosis: what do we know and what do we need to know? J Clin Oncol 2013;31(20):2521-2522

6 Cheesman WS. Influence of pregnancy on cancer of the breast. Ann Surg 1907;46(3):487-488

7 Haagensen CD, Stout AP. Carcinoma of the breast: II. Criteria of operability. Ann Surg 1943;118(5):859-870

8 Jensen EV, Desombre ER, Kawashima T, Suzuki T, Kyser K, Jungblut PW. Estrogen-binding substances of target tissues. Science 1967;158(3800):529-530
9 McGuire WL. Steroid hormone receptors and disease: breast cancer. Proc Soc Exp Biol Med 1979;162(1):22-25

10 Loibl S, Han SN, von Minckwitz G, et al. Treatment of breast cancer during pregnancy: an observational study. Lancet Oncol 2012;13(9):887-896

11 Azim HA Jr, Santoro L, Russell-Edu W, Pentheroudakis G, Pavlidis N, Peccatori FA. Prognosis of pregnancy-associated breast cancer: a meta-analysis of 30 studies. Cancer Treat Rev 2012;38(7):834-842

12 Amant F, von Minckwitz G, Han SN, et al. Prognosis of women with primary breast cancer diagnosed during pregnancy: results from an international collaborative study. J Clin Oncol 2013;31(20):2532-2539

13 Mueller BA, Simon MS, Deapen D, Kamineni A, Malone KE, Daling JR. Childbearing and survival after breast carcinoma in young women. Cancer 2003;98(6):1131-1140

14 Gwyn K, Theriault R. Breast cancer during pregnancy. Oncology (Williston Park) 2001;15(1):39-46, discussion 46, 49-51

15 Middleton LP, Amin M, Gwyn K, Theriault R, Sahin A. Breast carcinoma in pregnant women: assessment of clinicopathologic and immunohistochemical features. Cancer 2003;98(5):1055-1060

16 Davies MC, Jones AL. Pregnancy and Breast Cancer. Royal College of Obstetricians and Gynaecologists Green-top Guideline. 2011. London, United Kingdom: Royal College of Obstreticians and Gynaecologists 2011:1-15

17 Yang WT, Dryden MJ, Gwyn K, Whitman GJ, Theriault R. Imaging of breast cancer diagnosed and treated with chemotherapy during pregnancy. Radiology 2006;239(1):52-60

18 Kuerer HM, Gwyn K, Ames FC, Theriault RL. Conservative surgery and chemotherapy for breast carcinoma during pregnancy. Surgery 2002;131(1):108-110

19 Annane K, Bellocq JP, Brettes JP, Mathelin C. Infiltrative breast cancer during pregnancy and conservative surgery. Fetal Diagn Ther 2005;20(5):442-444

20 Filippakis GM, Zografos G. Contraindications of sentinel lymph node biopsy: are there any really? World J Surg Oncol 2007;5:10

21 Germann N, Goffinet F, Goldwasser F. Anthracyclines during pregnancy: embryo-fetal outcome in 160 patients. Ann Oncol 2004;15(1):146-150

22 Johnson PH, Gwyn K, Gordon N, et al. The treatment of pregnant women with breast cancer and the outcomes of the children exposed to chemotherapy in utero. J Clin Oncol 2005;23((Suppl ) 16) Abstract 540

23 Doll DC, Ringenberg QS, Yarbro JW. Antineoplastic agents and pregnancy. Semin Oncol 1989;16(5):337-346

24 Ebert U, Löffler H, Kirch W. Cytotoxic therapy and pregnancy. Pharmacol Ther 1997;74(2):207-220

25 Bader AA, Schlembach D, Tamussino KF, Pristauz G, Petru E. Anhydramnios associated with administration of trastuzumab and paclitaxel for metastatic breast cancer during pregnancy. Lancet Oncol 2007;8(1):79-81

26 Fanale MA, Uyei AR, Theriault RL, Adam K, Thompson RA. Treatment of metastatic breast cancer with trastuzumab and vinorelbine during pregnancy. Clin Breast Cancer 2005;6(4): 354-356

27 Pant S, Landon MB, Blumenfeld M, Farrar W, Shapiro CL. Treatment of breast cancer with trastuzumab during pregnancy. J Clin Oncol 2008;26(9):1567-1569

28 Sekar R, Stone PR. Trastuzumab use for metastatic breast cancer in pregnancy. Obstet Gynecol 2007;110(2 Pt 2):507-510

29 Shrim A, Garcia-Bournissen F, Maxwell C, Farine D, Koren G. Favorable pregnancy outcome following Trastuzumab (Herceptin) use during pregnancy-case report and updated literature review. Reprod Toxicol 2007;23(4):611-613 
30 Waterston AM, Graham J. Effect of adjuvant trastuzumab on pregnancy. J Clin Oncol 2006;24(2):321-322

31 Watson WJ. Herceptin (trastuzumab) therapy during pregnancy: association with reversible anhydramnios. Obstet Gynecol 2005;105(3):642-643

32 Witzel ID, Müller V, Harps E, Janicke F, Dewit M. Trastuzumab in pregnancy associated with poor fetal outcome. Ann Oncol 2008;19(1):191-192

33 Gainford MC, Clemons M. Breast cancer in pregnancy: are taxanes safe? Clin Oncol (R Coll Radiol) 2006;18(2):159

34 García-Manero M, Royo MP, Espinos J, Pina L, Alcazar JL, López G. Pregnancy associated breast cancer. Eur J Surg Oncol 2009;35(2):215-218

35 Gonzalez-Angulo AM, Walters RS, Carpenter RJ Jr, et al. Paclitaxel chemotherapy in a pregnant patient with bilateral breast cancer. Clin Breast Cancer 2004;5(4):317-319

36 Mir O, Berveiller P, Ropert S, et al. Emerging therapeutic options for breast cancer chemotherapy during pregnancy. Ann Oncol 2008;19(4):607-613
37 Navrozoglou I, Vrekoussis T, Kontostolis E, et al. Breast cancer during pregnancy: a mini-review. Eur J Surg Oncol 2008;34(8): 837-843

38 Molckovsky A, Madarnas Y. Breast cancer in pregnancy: a literature review. Breast Cancer Res Treat 2008;108(3):333-338

39 van Nes JG, van de Velde CJ. The preferred treatment for young women with breast cancer-mastectomy versus breast conservation. Breast 2006;15(Suppl 2):S3-S10

40 Theriault R, Hahn K. Management of breast cancer in pregnancy. Curr Oncol Rep 2007;9(1):17-21

41 Lenhard MS, Bauerfeind I, Untch M. Breast cancer and pregnancy: challenges of chemotherapy. Crit Rev Oncol Hematol 2008;67(3):196-203

42 Roche N. Follow-up after treatment for breast cancer in young women. Breast 2006;15(Suppl 2):S71-S75

43 Liberman L, Giess CS, Dershaw DD, Deutch BM, Petrek JA. Imaging of pregnancy-associated breast cancer. Radiology 1994;191(1):245-248

44 Keyser EA, Staat BC, Fausett MB, Shields AD. Pregnancyassociated breast cancer. Rev Obstet Gynecol 2012;5(2):94-99 